\title{
Mechanisms of action of steroid receptors in the regulation of gene transcription
}

\author{
M. G. Parker \\ Molecular Endocrinology Laboratory, Imperial Cancer Research Fund, Lincoln's Inn Fields, \\ London $W C 2 A 3 P X, U K$
}

\begin{abstract}
Summary. Steroid hormones regulate rates of transcription of certain genes by binding as a hormone-receptor complex to specific DNA sequences termed steroid-response elements. These elements consist of inverted repeats of the sequence TGTTCT for glucocorticoids, progestagens and androgens and TGACC for oestrogens. Domains for steroid binding, DNA binding and transcriptional activation have been defined in the mouse oestrogen receptor.
\end{abstract}

Keywords: steroid receptors; transcription

\section{Introduction}

Steroid receptors are members of a family of nuclear hormone receptors that function as transcription factors to regulate gene activity. The family also includes receptors for thyroid hormone, a number of vitamins and several others whose ligands have yet to be identified (Evans, 1988; Ham \& Parker, 1989). Following hormone binding to form a hormone-receptor complex, they interact with regulatory DNA sequences termed hormone-response elements. These can either stimulate promoter activity by acting as transcriptional enhancers, or repress transcription, probably by interfering with the activity of other promoter elements. Hormone-response elements contain inverted repeat sequences and to date correspond to one of two classes. The sequence TGTTCT appears to mediate the response of glucocorticoids (Scheidereit et al., 1986), progestagens (Strähle et al., 1987) and androgens (Ham et al., 1988) while the sequence TGACC appears to mediate the response of oestrogens (Klein-Hitpass et al., 1986), thyroid hormone and vitamin A (Umesono et al., 1988).

The receptors are all related in terms of the overall organization of their functional domains although they show considerable differences in their sizes. Krust et al. (1986) have proposed dividing the structure of receptors into six regions, $\mathrm{A}-\mathrm{F}$, on the basis of amino acid similarities in different portions of the protein. Region $C$, which is the most highly conserved region, is responsible for DNA binding specificity. Region $\mathrm{E}$ which is also conserved, contains the ligand binding domain. Transcriptional activation is achieved via multiple domains which have been mapped to the N-terminus (Regions A/B), DNA-binding region and the C-terminus (Region E). A scheme showing the location of these domains in the mouse oestrogen receptor is presented in Fig. 1 . The evidence to support this organization is summarized below.

\section{Steroid binding domain}

The steroid binding domain in the oestrogen receptor is located within Region E. Scatchard analysis of receptor mutants indicates that its C-terminal boundary maps between residues 507 and 538 (Table 1; Fawell et al., 1989). Since deletions throughout Region E between residues 265 and 588 


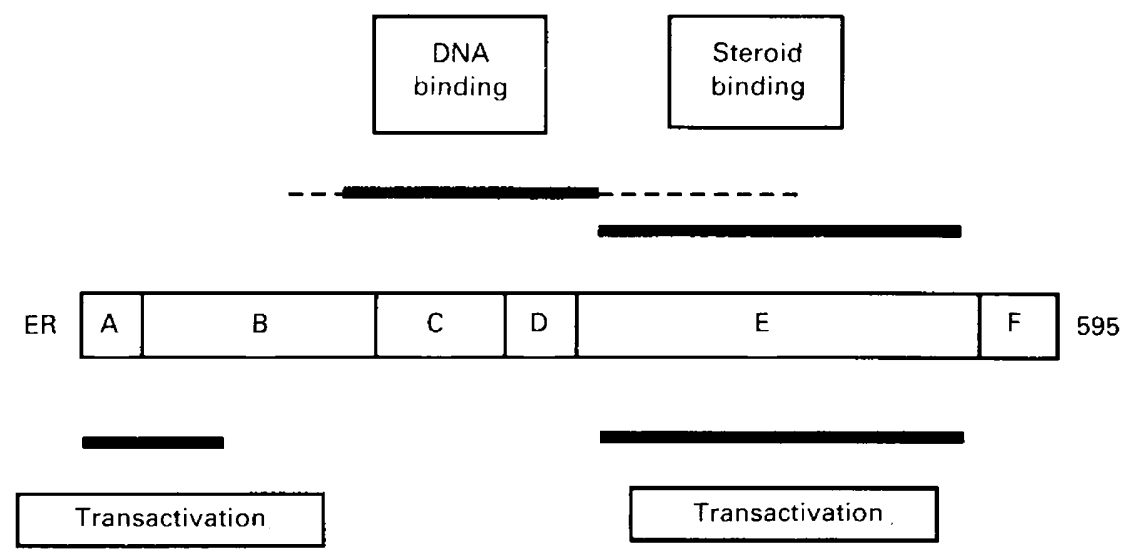

Fig. 1. Functional domains $(\mathrm{A}-\mathrm{F})$ in the mouse oestrogen receptor (ER).

Table 1. Binding affinities of mutant receptors for oestradiol

\begin{tabular}{lc}
\hline Deletion mutant & $K_{\mathrm{d}}(\mathrm{nM})$ \\
\hline $1-599$ & $0 \cdot 08$ \\
$121-552$ & $0 \cdot 12$ \\
$121-538$ & $0 \cdot 30$ \\
$121-507$ & $>50$ \\
\hline
\end{tabular}

abolish oestrogen binding, it is proposed that Region $\mathrm{E}$ may form a hydrophobic pocket in which only a small number of discrete residues contribute directly to ligand binding (Kumar et al., 1986).

\section{DNA binding domain}

Deletion mutants indicate that residues 121-315 of the mouse oestrogen receptor are sufficient for DNA binding (Lees et al., 1989). It is likely that the structure of the DNA-binding domain consists of two 'finger' structures generated by the co-ordination of zinc ions by cysteine and histidine residues (Freedman et al., 1988). These two 'fingers' are responsible for target gene specificity and the most critical amino acids appear to be three residues at the base of the first 'finger' (Mader et al., 1989). When the receptors are compared (Fig. 2) it can be seen that the three residues glycine, serine and valine are conserved in the receptors for glucocorticoids, progestagens, mineralocorticoids and androgens, while the glutamic acid, glycine and alanine/glycine residues are conserved in the receptors for oestrogens, thyroid hormone, retinoic acid and vitamin $\mathrm{D}$. Thus these two sets of three amino acids must play a key role in discriminating between TGTTCT and TGACC in the response elements.

\section{Transcriptional activation}

The ability of deletion mutants to stimulate transcription depends on the target promoter. There appear to be at least two domains responsible for this function within the mouse oestrogen receptor (Lees et al., 1989). The major domain resides in Region E, near the C-terminus, and depends on oestrogen binding for its activity. The second domain resides near the $\mathrm{N}$-terminus and is ligand 

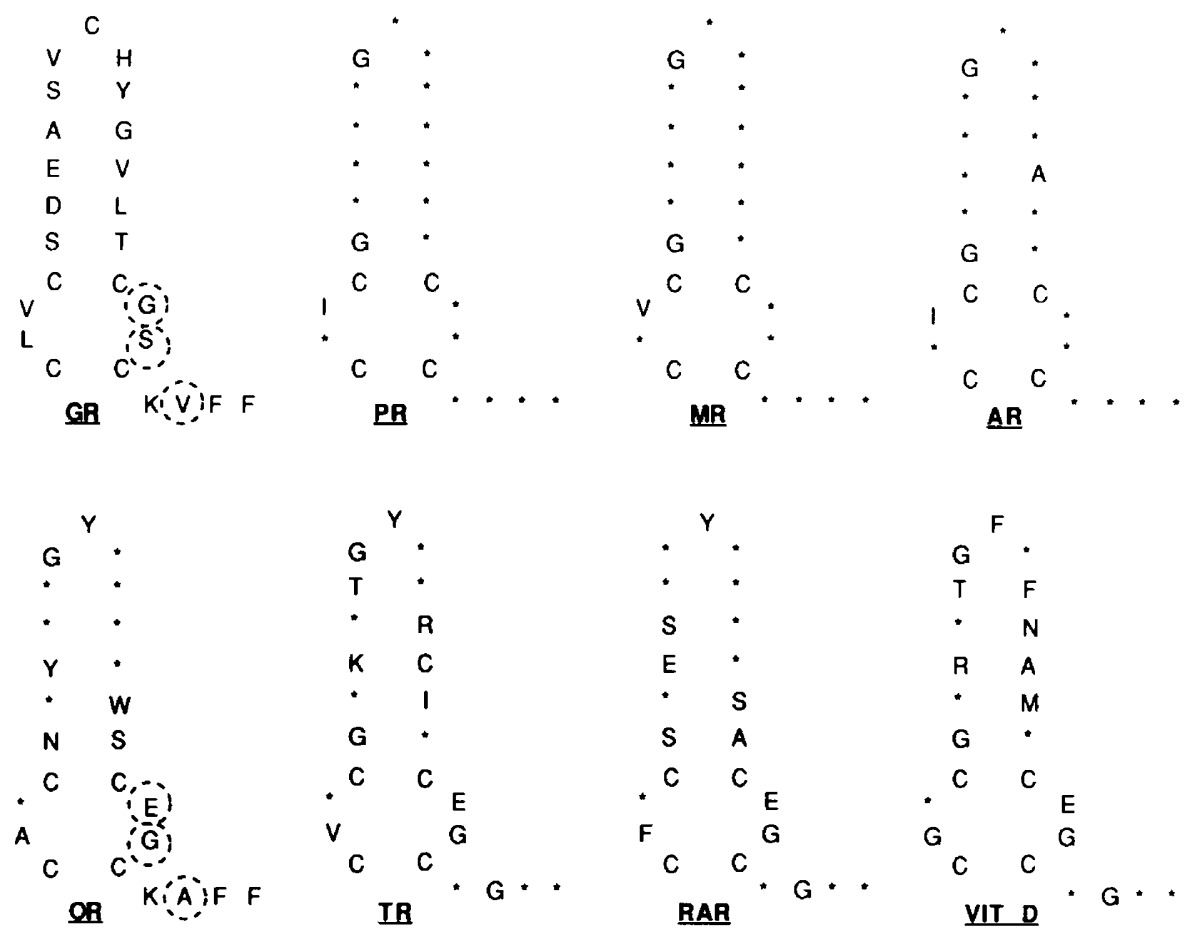

Fig. 2. Comparison of the first finger region of nuclear hormone receptors. The amino acid residues in the first finger of the glucocorticoid receptor (GR), were compared with those in the receptor for progestagen (PR), mineralocorticoid (MR), androgen (AR), oestrogen (OR), thyroid hormone (TR), retinoic acid or vitamin A (RAR) and vitamin D (VITD). Identical residues are shown $(\bullet)$ and differences with the appropriate amino acid. The residues which mediate target gene specificity (Mader et al., 1989) are circled.

independent. We have found that both domains are required for activation of the chicken vitellogenin A2 promoter but the C-terminal domain only is required for activation of an oestrogenresponse element placed in front of the thymidine kinase promoter.

Multiple transactivation domains may be a general feature of the steroid receptors. Although the precise location of most of these domains has not been determined, the sequences do not appear to be conserved between different classes of receptor. Therefore, at the present time it is not known how these domains function to stimulate transcription but it is likely to involve interactions with the basic transcription complex.

\section{References}

Evans, R.M. (1988) The steroid and thyroid hormone receptor superfamily. Science, $N Y \mathbf{2 4 0 , 8 8 9 - 8 9 5 . ~}$

Fawell, S.E., Lees, J.A. \& Parker, M.G. (1989) A proposed consensus steroid-binding sequence-a reply. Molec. Endocr. 3, 1002-1005.

Freedman, L.P., Luisi, B.F., Korszun, Z.R., Basavappa, R., Sigler, P.B. \& Yamamoto, K.R. (1988) The function and structure of the metal coordination sites within the glucocorticoid receptor DNA binding domain. Nature, Lond. 334, 543-546.

Ham, J. \& Parker, M.G. (1989) Regulation of gene expression by nuclear hormone receptors. Current Opinion in Cell Biology 1, 503-511.
Ham, J., Thomson, A., Needham, M., Webb, P. \& Parker, M. (1988) Characterization of response elements for androgens, glucocorticoids and progestins in mouse mammary tumour virus. Nucleic Acids Res. 16, 5263-5276.

Klein-Hitpass, L., Schorpp, M., Wagner, U. \& Ryffel, G.U. (1986) An estrogen-responsive element derived from the 5 ' flanking region of the Xenopus viellogenin A2 gene functions in transfected human cells. Cell 46, 1053-1061.

Krust, A., Green, S., Argos, P., Kumar, V., Walter, P., Bornert, J.-M. \& Chambon, P. (1986) The chicken oestrogen receptor sequence: homology with v-erb A 
and the human oestrogen and glucocorticoid receptors. EMBO J. 5, 891-897.

Kumar, V., Green, S., Staub, A. \& Chamben, P. (1986) Localisation of the oestradiol-binding and putative DNA-binding domains of the human oestrogen receptor. EMBO J. 5, 2231-2236.

Lees, J.A., Fawell, S.E. \& Parker, M.G. (1989) Identification of constitutive and steroid dependent transactivation domains in the mouse oestrogen receptor. Nucleic Acids Res. 17, 5477-5488.

Mader, S., Kumar, V., de Verneuil, H. \& Chambon, P. (1989) Three amino acids of the oestrogen receptor are essential to its ability to distinguish an oestrogen from a glucocorticoid-responsive element. Nature, Lond. 338, 271-274.
Scheidereit, C., Westphal, H.M., Carlson, C., Bosshard, H. \& Beato, M. (1986) Molecular model of the interaction between the glucocorticoid receptor and the regulatory elements of inducible gene. DNA 5, 383-391.

Strähle, U., Klock, G. \& Schütz, G. (1987) A DNA sequence of 15 base pairs is sufficient to mediate both glucocorticoid and progesterone induction of gene expression. Proc. natn. Acad. Sci. USA 84, 7871-7875.

Umesono, K., Giguere, V., Glass, C.K., Rosenfeld, M.G. \& Evans, R.M. (1988) Retinoic acid and thyroid hormone induce gene expression through a common responsive element. Nature, Lond. 336, 262-264. 